\title{
SENSITIVITY AND SPECIFICITY OF FENYÖ-LINDBERG AND TEICHER SCORES IN THE DIAGNOSIS OF ACUTE APPENDICITIS IN WOMEN
}

\author{
Zrinko Madžar ${ }^{1}$, Mario Kopljar ${ }^{1,2}$, Tomislav Madžar ${ }^{3}$, Marko Mesić4, \\ Dubravka Mužina Mišić ${ }^{1}$, Slaven Čiček ${ }^{1}$ and Mario Zovak ${ }^{1,5}$ \\ ${ }^{1}$ Clinical Department of Surgery, Sestre milosrdnice University Hospital Center, Zagreb; \\ ${ }^{2}$ Faculty of Medicine, Josip Juraj Strossmayer University of Osijek; \\ ${ }^{3}$ School of Medicine, University of Zagreb; \\ ${ }^{4}$ Clinical Department of Surgery, Zagreb Children's Hospital; \\ ${ }^{5}$ School of Dental Medicine, University of Zagreb, Zagreb, Croatia
}

\begin{abstract}
SUMMARY - The aim of the study was to assess diagnostic accuracy (sensitivity and specificity) of Fenyö-Lindberg and Teicher scores for distinguishing patients that need immediate surgical treatment from the others, in a female population from an urban setting. The study prospectively included 130 female patients admitted to the emergency department with abdominal pain indicating acute appendicitis. The scores and parameters of validity were calculated and compared to definitive diagnosis. For Fenyö-Lindberg score of -17 or less, $84.5 \%$ sensitivity, $55.6 \%$ specificity, $87.9 \%$ positive predictive value (PPV) and $48.4 \%$ negative predictive value (NPV) were recorded. For cut-off value greater or equal to -2 , there was $59.2 \%$ sensitivity, $77.8 \%$ specificity, $91 \%$ PPV and $33.3 \%$ NPV. The Receiver Operating Characteristic (ROC) curve analysis of Fenyö-Lindberg score showed that the best single cut-off value for discriminating acute appendicitis in the study population was -15 . For Teicher score, values greater than -3 yielded $89.3 \%$ sensitivity and $22.2 \%$ specificity, $81.4 \%$ PPV and $35.3 \%$ NPV. In conclusion, Fenyö-Lindberg score could be used as an additional tool to exclude appendicitis and avoid unnecessary appendectomies. Teicher score may help in recognizing patients with appendicitis. None of the two scores can indicate or decline appendectomy in all cases. Scoring systems may be useful for pointing to important clinical signs and symptoms in specific subpopulations.
\end{abstract}

Key words: Appendicitis - diagnosis; Women; Sensitivity; Specificity; ROC curve; Predictive value

\section{Introduction}

Acute appendicitis is one of the most common acute surgical conditions that require prompt diagnosis and treatment in order to minimize morbidity and avoid serious complications. Besides clinical signs and symptoms and routine laboratory assessments that are basic tools in establishing diagnosis, different scoring systems based on these features are in use. Although

Correspondence to: Mario Kopljar, $M D, P h D$, Clinical Department of Surgery, Sestre milosrdnice University Hospital Center, Vinogradska c. 29, HR-10000 Zagreb, Croatia

E-mail:kopljar@yahoo.com

Received February 15, 2016, accepted May 18, 2016 modern imaging techniques, such as ultrasound or computer tomography (CT) scanning ${ }^{1,2}$ can achieve high accuracy, these are often dependent on the observer or expose patients to high doses of radiation, which is especially important to consider in the population of young patients and fertile women. Therefore, accurate identification of patients that require immediate surgery as opposed to those that will benefit from active observation is not always easy ${ }^{3}$.

There are a number of scoring systems that have been constructed to help in decision making in doubtful cases, including Fenyö-Lindberg et al. ${ }^{4,5}$, Teicher et $a l .{ }^{6}$, and several others. Scores are based on routine 
clinical and laboratory assessments, so they do not increase the cost and duration of diagnostic procedure, and are simple to use in a variety of clinical settings.

However, when scores were applied to different groups of patients and clinical settings, differences in sensitivity and specificity were observed, usually with worse performance if applied in the populations and institutions other than those in which they were originally created ${ }^{4,7}$. Also, their application in different populations could be impaired by geographic variation in the incidence and clinical pattern of acute abdominal pain ${ }^{8}$. Rates of $15 \%-30 \%$ of negative laparotomies and laparoscopies have been reported ${ }^{9-11}$ in suspected acute appendicitis, and accurate diagnosis of acute appendicitis is particularly difficult in women, especially those of fertile age ${ }^{9-12}$. In this population, the relatively low accuracy of routine diagnostic methods (clinical and laboratory assessment) results in a high negative appendectomy rate because of gynecologic disorders with clinical features similar to appendicitis ${ }^{12}$.

In this study, we analyzed diagnostic accuracy of two scoring systems (Fenyö-Lindberg and Teicher) and of clinical assessment in distinguishing patients that need immediate surgical treatment from those that will benefit from additional diagnostic procedures or active observation, in a female population in an urban setting. These scores are designed for general population, and their validity in diagnostically difficult female subpopulation has not yet been fully investigated.

\section{Patients and Methods}

\section{Patients}

This study was designed as a prospective 12 -month study and included all female patients admitted to the Surgical Emergency Department with abdominal pain indicating acute appendicitis and having undergone appendectomy. Patients with abdominal pain of other known causes and patients with a history of appendectomy were not included. A total of 130 female patients were included. A surgical resident (junior physician) and a surgeon (consultant) examined patients in the emergency department and the senior surgeon then indicated appendectomy based on clinical and laboratory findings, unaware of the score. In this way, the score did not influence treatment.

\section{Scores}

Fenyö-Lindberg and Teicher scores were calculated as described for all patients in the study (Table 1) ) $^{4,6}$. Data used for calculation were obtained from the structured admission records. The same person (surgery resident) collected data, filled the records and calculated scores at the time of initial assessment. The values of Fenyö-Lindberg score of -2 or more were taken as indicative of acute appendicitis, while the values of -17 or less indicated nonspecific abdominal pain $^{4}$. In case of Teicher score, the cut-off value of -3 was chosen to predict acute appendicitis ${ }^{6}$.

\section{Gold standard of diagnosis}

Definitive diagnosis was established using both intraoperative findings and histologic diagnosis (reference standard). Four groups of patients were formed based on the worst finding: 1) without inflamed appendix; 2) with inflamed appendix; 3) with gangrenous appendix; and 4) with perforated appendix.

\section{Statistics}

For analysis, logistic regression was performed to obtain variables that independently and significantly predict acute appendicitis. Also, for both scores used in this study, the parameters of validity were calculated, i.e. sensitivity, specificity, positive predictive value (PPV) and negative predictive value (NPV), with 95\% confidence interval $(95 \% \mathrm{CI})$.

For both scores, the Receiver Operating Characteristic (ROC) curve analysis was performed to determine the best single cut-off value for discriminating acute appendicitis from other causes of abdominal pain (corresponding to highest accuracy, i.e. minimal false-negative and false-positive results).

For clinical diagnosis, only PPV could be calculated, since all patients included in the study underwent surgery. The values of $\mathrm{p}<0.05$ were used to determine statistical significance in all tests.

All the procedures were performed in accordance with ethical standards set by the institutional or regional responsible committee on human experimentation and with the Helsinki Declaration of 1975 , as revised in 1983.

\section{Results}

The mean age of study patients was 39.2 years (standard deviation (SD), 19.6). In 103 (79.2\%) pa- 
Table 1. Fenyö-Lindberg and Teicher Scores

a) Fenyö-Lindberg score

\begin{tabular}{|l|l|c|}
\hline Parameter & Value & Points \\
\hline Constant & & -10 \\
\hline Gender & Male & 8 \\
& Female & -8 \\
\hline White blood cell count & $<9 \times 10^{9} / \mathrm{L}$ & -15 \\
& $9-13.9 \times 10^{9} / \mathrm{L}$ & 2 \\
& $>14 \times 10^{9} / \mathrm{L}$ & 10 \\
\hline Pain duration & $<24 \mathrm{~h}$ & 3 \\
& $24-48 \mathrm{~h}$ & 0 \\
& $>48 \mathrm{~h}$ & -12 \\
\hline Progression of pain & Yes & 3 \\
& No & -4 \\
\hline Relocation of pain & Yes & 7 \\
& No & -9 \\
\hline Vomiting & Yes & 7 \\
& No & -5 \\
\hline Aggravation with cough & Yes & 4 \\
& No & -11 \\
\hline Rebound tenderness & Yes & 5 \\
& No & -10 \\
\hline Rigidity & Yes & 15 \\
& No & -4 \\
\hline Pain outside right lower & Yes & -6 \\
quadrant & No & 4 \\
\hline
\end{tabular}

b) Teicher score

\begin{tabular}{|l|l|c|}
\hline Parameter & Value & Points \\
\hline Gender & Male & +2 \\
& Female & -1 \\
\hline Age (yrs) & $20-39$ & -1 \\
& $\geq 50$ & +3 \\
& $<20$ or $40-49$ & 0 \\
\hline Duration of symptoms & 1.5 & +2 \\
(days) & 2 & +1 \\
& 3 & -3 \\
& $\leq 1$ & 0 \\
\hline Genital or urinary symptoms & Present & -3 \\
& Absent & 0 \\
\hline Muscle spasm in right lower & Involuntary & +3 \\
quadrant & None & -3 \\
\hline Rectal mass on right side & Present & -3 \\
& Absent & 0 \\
\hline White blood cell count & $<10^{9} / \mathrm{L}$ & -3 \\
& $10-13 \times 10^{9} / \mathrm{L}$ & 0 \\
& $>13 \times 10^{9} / \mathrm{L}$ & +2 \\
\hline
\end{tabular}

Table 2. Frequencies of acutely inflamed, gangrenous and perforated appendix among 130 female patients admitted for acute appendicitis

\begin{tabular}{|l|l|l|}
\hline Appendix & Frequency & $\%$ \\
\hline Non-inflamed & 27 & 20.8 \\
Phlegmonous & 68 & 52.3 \\
Gangrenous & 19 & 14.6 \\
Perforated & 16 & 12.3 \\
Total & 130 & 100.0 \\
\hline
\end{tabular}

Table 3. Logistic regression analysis assessing multiple predictors associated with acute appendicitis

\begin{tabular}{|l|l|l|}
\hline Predictor & Wald & $\mathrm{p}$ \\
\hline Age $(\mathrm{yrs})$ & 4.94896 & 0.0261 \\
Rectal temperature $\left({ }^{\circ} \mathrm{C}\right)$ & 5.51623 & 0.0188 \\
Axillary-rectal difference $\left({ }^{\circ} \mathrm{C}\right)$ & 0.00087 & 0.9764 \\
Leukocyte count $\left(10^{9} / \mathrm{L}\right)$ & 14.16533 & 0.0002 \\
Duration of symptoms $(\mathrm{h})$ & 4.72847 & 0.0297 \\
Nausea or vomiting $(\mathrm{yes} / \mathrm{no})$ & 5.91161 & 0.0150 \\
\hline
\end{tabular}

tients, diagnosis of acute appendicitis was confirmed. The frequency of acutely inflamed, gangrenous or perforated appendix is shown in Table 2. In 27 (20.8\%) patients there were no macroscopic or microscopic signs of acute appendicitis. Among these patients, there was rupture of ovarian cyst in four patients, acute adnexitis in two patients, ischemic colitis and perforation of duodenal ulcer in one patient each, while 19 patients were considered as having acute nonspecific abdominal pain because there were no signs indicating other causes of abdominal pain.

Several variables were analyzed by logistic regression. Age, rectal temperature, leukocyte count, duration of symptoms, and presence of nausea/vomiting were found to be positively, independently and significantly associated with acute appendicitis (Table 3).

At the Fenyö-Lindberg score cut-off value -17 , 84.5\% sensitivity, $55.6 \%$ specificity, $87.9 \% \mathrm{PPV}$ and 48.4\% NPV were recorded. At the cut-off value -2 , 59.2\% sensitivity, $77.8 \%$ specificity, $91.0 \% \mathrm{PPV}$ and 33.3\% NPV were obtained. Furthermore, ROC curve analysis for Fenyö-Lindberg score revealed that the best single cut-off value was -15 , yielding $78.6 \%$ sensitivity, $70.4 \%$ specificity, $91.0 \% \mathrm{PPV}$, and $46.3 \% \mathrm{NPV}$ (Table 4, Fig. 1). For Teicher score, the cut-off value -3 
Table 4. Validity of Fenyö-Lindberg score for diagnosis of acute appendicitis with different cut-off points

\begin{tabular}{|l|l|l|l|l|}
\hline Cut-off point & Sensitivity $(95 \% \mathrm{CI})$ & Specificity $(95 \% \mathrm{CI})$ & PPV $(\%)$ & NPV $(\%)$ \\
\hline$\geq-59$ & $100.0(96.4-100.0)$ & $0.0(0.0-12.9)$ & 79.2 & - \\
$\ldots$ & $\ldots$ & $\ldots$ & $\ldots$ & $\ldots$ \\
$>-17$ & $84.5(76.0-90.8)$ & $55.6(35.3-74.5)$ & 87.9 & 48.4 \\
$>-16$ & $81.6(72.7-88.5)$ & $66.7(46.0-83.4)$ & 90.3 & 48.6 \\
$>-15$ & $78.6(69.5-86.1)$ & $70.4(49.8-86.2)$ & 91.0 & 46.3 \\
$\ldots$ & $\ldots$ & $\ldots$ & $\ldots$ & $\ldots$ \\
$>-2$ & $59.2(49.1-68.8)$ & $77.8(57.7-91.3)$ & 91.0 & 33.3 \\
$>-1$ & $58.3(48.1-67.9)$ & $81.5(61.9-93.6)$ & 92.3 & 33.8 \\
$\ldots$ & $\ldots$ & $\ldots$ & $\ldots$ & $\ldots$ \\
$>40$ & $0.0(0.0-3.6)$ & $100.0(87.1-100.0)$ & - & 20.8 \\
\hline
\end{tabular}

95\% CI = 95\% confidence interval; PPV = positive predictive value; NPV = negative predictive value

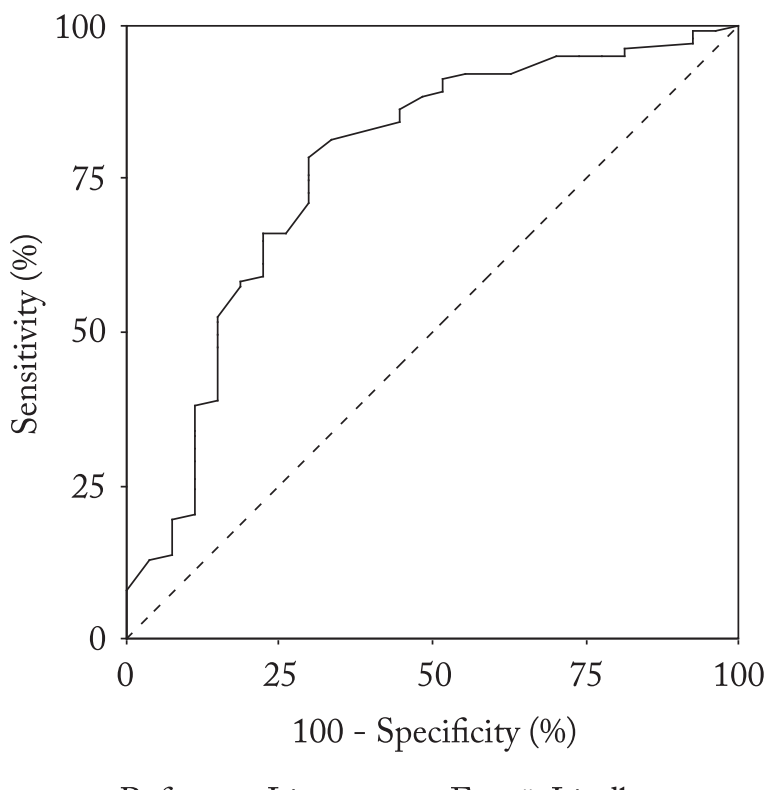

-.. - Reference Line —— Fenyö-Lindberg score

Fig. 1. ROC curve for Fenyö-Lindberg score for diagnosis of acute appendicitis.

resulted in $89.3 \%$ sensitivity, $22.2 \%$ specificity, $81.4 \%$ PPV and 35.3\% NPV. Using ROC analysis, the best single cut-off point for Teicher score was 2, with $61.2 \%$ sensitivity, $66.7 \%$ specificity, $87.5 \% \mathrm{PPV}$ and $31.0 \%$ NPV. The PPV of clinical diagnosis was 79.2\% (Table 5, Fig. 2).

The parameters of validity of both scoring systems, as well as of clinical diagnosis are shown in Table 6, together with the number of correctly and incorrectly classified patients.

\section{Discussion}

Comparison of the clinical diagnosis $\mathrm{PPV}$ and $\mathrm{Fe}-$ nyö-Lindberg score PPV revealed that, irrespective of the Fenyö-Lindberg score taken $(-2,-15$ or -17$)$, the PPV of clinical diagnosis was lower in all cases (Table 6), resulting in a higher number of negative appendectomies (27 in our study). For example, in case of the cut-off -15 , PPV was $91 \%$, which would in this study yield 8 negative appendectomies. On the other hand, all tests had low NPV, indicating low probability that patients had no appendicitis if the test was considered negative.

For Teicher score, values greater than -3 resulted in 89.3\% sensitivity, thus overlooking appendicitis in 11 patients. At the same time, it had very low specificity (22.2\%), giving low clinical security in excluding appendicitis (only 6 out of 27 patients could be excluded) (Tables 5 and 6).

Considering the quality of diagnosis, a $15 \%$ rate of negative appendectomies, $10 \%$ rate of negative laparotomies, $35 \%$ rate of potential perforations, $15 \%$ rate of overlooked perforations and 5\% rate of overlooked acute appendicitis are to be expected ${ }^{7,13}$. Compared to previously published data ${ }^{9-11}$, there was a higher rate of negative appendectomies in our study (20.8\% vs. 15\%), higher rate of negative laparotomies (14.6\% vs. 10\%), lower rate of potential perforations ( $26.9 \%$ vs. $35 \%)$ and lower rate of overlooked perforations $(12.3 \%$ vs. $15 \%)$. Since all patients were eventually operated on, the rate of overlooked appendicitis was zero.

For Fenyö-Lindberg score (at cut off point -2), results in our study showed lower sensitivity $(59 \%$ vs. 
Table 5. Validity of Teicher score for diagnosis of acute appendicitis with different cut-off points

\begin{tabular}{|l|l|l|l|l|}
\hline Cut-off point & Sensitivity $(95 \% \mathrm{CI})$ & Specificity $(95 \% \mathrm{CI})$ & PPV $(\%)$ & NPV (\%) \\
\hline$\geq-7$ & $100.0(96.4-100.0)$ & $0.0(0.0-12.9)$ & 79.2 & - \\
$\ldots$ & $\ldots$ & $\ldots$ & $\ldots$ & $\ldots$ \\
$>-3$ & $89.3(81.7-94.5)$ & $22.2(8.7-42.3)$ & 81.4 & 35.3 \\
$>-2$ & $85.4(77.1-91.6)$ & $33.3(16.6-54.0)$ & 83.0 & 37.5 \\
$\ldots$ & $\ldots$ & $\ldots$ & $\ldots$ & $\ldots$ \\
$>2$ & $61.2(51.1-70.6)$ & $66.7(46.0-83.4)$ & 87.5 & 31.0 \\
$>9$ & $0.0(0.0-3.6)$ & $100.0(87.1-100.0)$ & - & 20.8 \\
\hline
\end{tabular}

95\% CI = 95\% confidence interval; $\mathrm{PPV}=$ positive predictive value; NPV = negative predictive value

62\%), higher specificity (77.8\% vs. 62\%), higher PPV (91.0\% vs. 83\%) and lower NPV (33.3\% vs. $44 \%)$ as compared with previously published data ${ }^{5}$. Also, in this study, ROC curve analysis revealed that the best single cut-off value for discriminating acute appendicitis from other abdominal pain causes was -15 , showing 91\% PPV (Table 4, Fig. 1). The possible reason for these differences could be different geographical settings of these two studies ${ }^{8}$.

In order to improve diagnostic accuracy, several easy to use scoring systems have been developed and tested ${ }^{3,4,14,15}$. Although scoring systems could be useful in the original setting in the population for which they were originally developed, they do not take into consideration different diagnostic value of each parameter in different subpopulations (e.g., children, women, elderly, geographic differences, etc.). Therefore, scores often did not show the same results if applied in different settings. This was the reason for developing new scoring systems and their re-evaluation in different settings ${ }^{16}$. Age and gender are factors that influence clinical presentation of acute abdominal pain ${ }^{4,7,8}$. It is known that extreme age groups have a higher rate of perforation ${ }^{15}$. It has been reported that Fenyö-Lindberg score, when applied to general population, has better PPV as compared with clinician diagnosis 5 . When stratified by gender, PPV of Fenyö-Lindberg score showed significant difference compared with PPV obtained by clinician diagnosis in male population. However, there was significant difference when applied to female population in favor of the score. Comparing these two populations, there was higher PPV in the male population ${ }^{5}$. Accordingly, differences should be respected and validity of a score varies among different subpopulations.

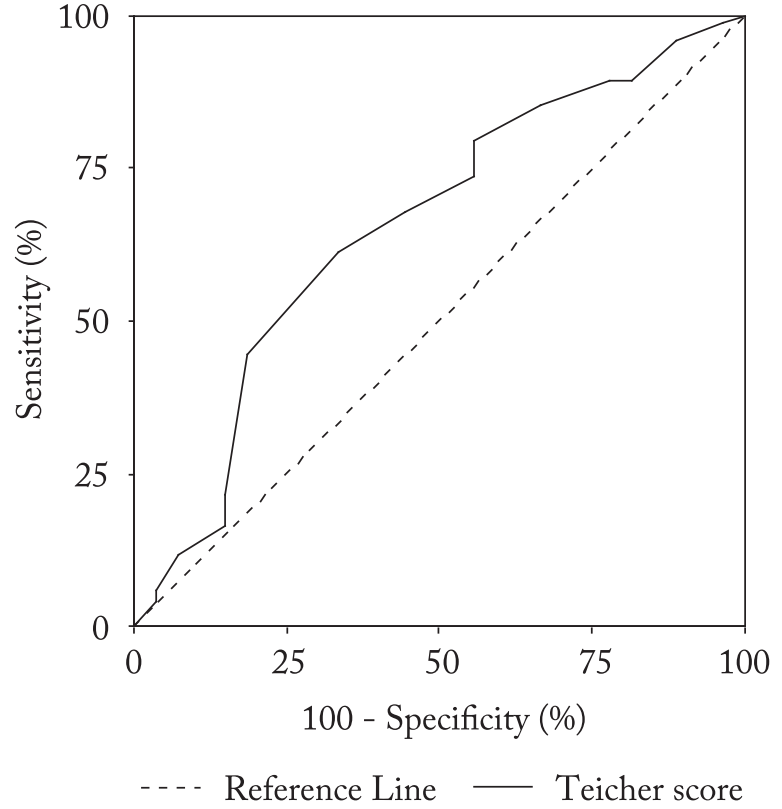

Fig. 2. ROC curve for Teicher score for diagnosis of acute appendicitis.

Not all scores have clear cut-off points for decision making on the diagnosis of acute appendicitis, as demonstrated for Fenyö-Lindberg score in this study. In order to determine safe cut-off values for different scores, defining specificities and sensitivities in different subpopulations may prove helpful.

Modern imaging techniques and diagnostic laparoscopy are becoming the main diagnostic aids to clinical diagnosis of acute abdominal pain, especially in doubtful cases because they provide more accurate and objective diagnosis ${ }^{17-19}$.

It has been generally considered that it is safer to remove normal appendix in questionable cases ${ }^{14}$, than postponing surgery in order to increase the level of di- 
Table 6. Validity of Fenyö-Lindberg and Teicher scoring systems and of clinical diagnosis

\begin{tabular}{|c|c|c|c|c|c|c|c|c|}
\hline $\begin{array}{l}\text { Diagnostic } \\
\text { method }\end{array}$ & $\begin{array}{c}\text { Sensitivity } \\
(\%)\end{array}$ & $\begin{array}{c}\text { No. of } \\
\text { overlooked } \\
\text { appendicitis }\end{array}$ & $\begin{array}{c}\text { Specificity } \\
(\%)\end{array}$ & $\begin{array}{c}\text { No. of } \\
\text { excluded } \\
\text { appendicitis }\end{array}$ & $\begin{array}{r}\text { PPV } \\
(\%)\end{array}$ & $\begin{array}{c}\text { No. of } \\
\text { negative } \\
\text { appendectomies }\end{array}$ & $\begin{array}{l}\text { NPV } \\
(\%)\end{array}$ & $\begin{array}{l}\text { No. of positive } \\
\text { appendectomies }\end{array}$ \\
\hline $\begin{array}{l}\text { Fenyö- } \\
\text { Lindberg, } \\
\text { cut off -17 }\end{array}$ & 84.5 & 16 & 55.6 & 15 & 87.9 & 12 & 48.4 & 87 \\
\hline $\begin{array}{l}\text { Fenyö- } \\
\text { Lindberg, } \\
\text { cut off -15 }\end{array}$ & 78.6 & 22 & 70.4 & 19 & 91.0 & 8 & 46.3 & 81 \\
\hline $\begin{array}{l}\text { Fenyö- } \\
\text { Lindberg, } \\
\text { cut off -2 }\end{array}$ & 59.2 & 42 & 77,8 & 21 & 91.3 & 6 & 34.4 & 61 \\
\hline $\begin{array}{l}\text { Teicher, } \\
\text { cut off }-3\end{array}$ & 89.3 & 11 & 22.2 & 6 & 81.4 & 21 & 35.3 & 92 \\
\hline $\begin{array}{l}\text { Teicher, } \\
\text { cut-off } 2\end{array}$ & 61.2 & 40 & 66.7 & 18 & 87.5 & 9 & 31.0 & 63 \\
\hline $\begin{array}{l}\text { Clinical } \\
\text { diagnosis }\end{array}$ & - & - & - & 0 & 79.2 & 27 & - & 103 \\
\hline
\end{tabular}

$\mathrm{PPV}=$ positive predictive value $\mathrm{NPV}=$ negative predictive value

agnostic accuracy in patients with acute abdominal pain because delaying can result in a higher rate of perforation ${ }^{20}$. The problem of this practice is, on the other hand, the high rate of negative appendectomies $(15 \%-30 \%)^{21}$. Prolonged observation may result in perforated appendix with worse outcome, which could have been avoided.

Results of this study indicate that using FenyöLindberg score could be useful as an additional tool in excluding appendicitis and avoiding unnecessary appendectomies. On the other hand, if diagnosis is made only by the score, there is a possibility of overlooking patients that need to be operated on. Teicher score could be helpful in recognizing patients that need appendectomy but at the same time gives a high rate of false-positive results. It is obvious that neither the scores nor clinical diagnosis are satisfactory diagnostic tools on their own. Probably a combination of all of them should be used in doubtful cases in order to achieve better diagnostic accuracy. Further clinical trials should be performed to assess this hypothesis.

Although a relatively small number of patients were included in this study, results showed marked differences when different scores and different cut-off values were used. In our study, all female patients admitted to our emergency department for acute appen- dicitis during a 12-month period were included. In this way, uniform diagnostic criteria and scoring were ensured, which may not be possible in a multicenter trial or during longer period of time.

Based upon the results of this study, we conclude that none of the two scoring systems analyzed can indicate or decline appendectomy in all cases. Also, using scores in the subpopulations other than the one for which they were originally developed requires additional testing and considering different cut-off points.

\section{References}

1. Albiston E. The role of radiological imaging in the diagnosis of acute appendicitis. Can J Gastroenterol. 2002;16:451-63.

2. Zielke A, Sitter H, Rampp T, Bohrer T, Rothmund M. Clinical decision-making, ultrasonography, and scores for evaluation of suspected acute appendicitis. World J Surg. 2001;25:578-84, http://dx.doi.org/10.1007/s002680020078

3. Christian F, Christian GP. A simple scoring system to reduce the negative appendicectomy rate. Ann R Coll Surg Eng1. 1992;74:281-5.

4. Fenyö G, Lindberg G, Blind P, Enochsson L, Oberg A. Diagnostic decision support in suspected acute appendicitis: validation of a simplified scoring system. Eur J Surg. 1997;163:831-8.

5. Enochsson L, Gudbjartsson T, Hellberg A, Rudberg C, Wenner $\mathrm{J}$, Ringqvist I, et al. The Fenyo-Lindberg scoring system for ap- 
pendicitis increases positive predictive value in fertile women - a prospective study in 455 patients randomized to either laparoscopic or open appendectomy. Surg Endosc. 2004;18:1509-13.

6. Teicher I, Landa B, Cohen M, Kabnick LS, Wise L. Scoring system to aid in diagnoses of appendicitis. Ann Surg.1983; 198:753-9.

7. Ohmann C, Yang Q, Franke C. Diagnostic scores for acute appendicitis. Abdominal Pain Study Group. Eur J Surg. 1995; 161:273-81.

8. Sitter H, Hoffmann S, Hassan I, Zielke A. Diagnostic score in appendicitis. Validation of a diagnostic score (Eskelinen score) in patients in whom acute appendicitis is suspected. Langenbecks Arch Surg. 2003;18:18, http://dx.doi.org/10.1007/ s00423-003-0436-9

9. Andersson RE, Hugander A, Thulin AJ. Diagnostic accuracy and perforation rate in appendicitis: association with age and sex of the patient and with appendicectomy rate. Eur J Surg. 1992;158:37-41.

10. Pieper R, Kager L. The incidence of acute appendicitis and appendectomy. An epidemiological study of 971 cases. Acta Chir Scand. 1982;148:45-9.

11. van den Broek WT, Bijnen BB, Rijbroek B, Gouma DJ. Scoring and diagnostic laparoscopy for suspected appendicitis. Eur J Surg. 2002;168:349-54.

12. Borgstein PJ, Gordijn RV, Eijsbouts QA, Cuesta MA. Acute appendicitis - a clear-cut case in men, a guessing game in young women. A prospective study on the role of laparoscopy. Surg Endosc. 1997;11:923-7.

13. Zielke A, Hasse C, Sitter H, Rothmund M. Influence of ultrasound on clinical decision making in acute appendicitis: a pro- spective study. Eur J Surg. 1998;164:201-9, http://dx.doi. org/10.1080/110241598750004652

14. Jones PF. Suspected acute appendicitis: trends in management over 30 years. Br J Surg. 2001;88:1570-7, http://dx.doi. org/10.1046/j.0007-1323.2001.01910.x

15. Koepsell TD, Inui TS, Farewell VT. Factors affecting perforation in acute appendicitis. Surg Gynecol Obstet. 1981;153: 508-10.

16. Ohmann C, Franke C, Yang Q, Margulies M, Chan M, van Elk PJ, et al. Diagnostic score for acute appendicitis. Chirurg. 1995;66:135-41.

17. Navez B, Delgadillo X, Cambier E, Richir C, Guiot P. Laparoscopic approach for acute appendicular peritonitis: efficacy and safety: a report of 96 consecutive cases. Surg Laparosc Endosc Percutan Tech. 2001;11:313-6.

18. Bouillot JL, Ruiz A, Alamowitch B, Capuano G, Aouad K, Fourmestraux J, et al. Suspected acute appendicitis. Role of enhanced helical computed tomography. Prospective study of 100 patients. Ann Chir. 2001;126:427-33.

19. Rettenbacher T, Hollerweger A, Gritzmann N, Gotwald T, Schwamberger K, Ulmer H, et al. Appendicitis: should diagnostic imaging be performed if the clinical presentation is highly suggestive of the disease? Gastroenterology. 2002;123: 992-8.

20. Malt RA. The perforated appendix. N Engl J Med. 1986;315: 1546-7, http://dx.doi.org/10.1056/NEJM198612113152409

21. Douglas CD, Macpherson NE, Davidson PM, Gani JS. Randomised controlled trial of ultrasonography in diagnosis of acute appendicitis, incorporating the Alvarado score. BMJ. 2000;321:919-22.

Sažetak

\section{OSJETLJIVOST I SPECIFIČNOST FENYÖ-LINDBERGOVA I TEICHEROVA SUSTAVA BODOVANJA U DIJAGNOSTICI AKUTNE UPALE CRVULJKA U ŽENA}

\section{Z. Madžar, M. Kopljar, T. Madžar, M. Mesić, D. Mužina Mišić, S. Čiček i M. Zovak}

Cilj istraživanja bio je analizirati dijagnostičku točnost (osjetljivost i specifičnost) Fenyö-Lindbergove i Teicherove bodovne ljestvice u postavljanju dijagnoze akutne upale crvuljka u ženskoj populaciji u urbanom okruženju. U studiju je prospektivno uključeno 130 bolesnica primljenih u hitnoj službi s bolovima u trbuhu i sumnjom na akutni apendicitis. Rezultati i parametri valjanosti izračunati su i uspoređeni s obzirom na konačnu dijagnozu. Za vrijednosti Fenyö-Lindbergova zbira -17 ili manje nađena je osjetljivost od $84,5 \%$, specifičnost od $55,6 \%$, pozitivna prediktivna vrijednost (PPV) od $87,9 \%$ i negativna prediktivna vrijednost (NPV) od 48,4\%. Za vrijednosti istoga zbira većeg ili jednakog -2 utvrđena je osjetliivost od $59,2 \%$, specifičnost od 77,8\%, PPV od 91\% i NPV od 33,3\%. Usporedba krivulja ROC za Fenyö-Lindbergov zbir pokazala je da je najbolja pojedinačna granična vrijednost u proučavanoj populaciji u svrhu diskriminacije akutne upale crvuljka -15 . Za Teicherov zbir vrijednosti veće od -3 pokazale su osjetljivost od 89,3\%, specifičnost od 22,2\%, PPV od 81,4\% i NPV od 35,3\%. U zaključku, Fenyö-Lindbergov zbir se može koristiti kao dodatni alat u isključivanju upale crvuljka i izbjegavanju nepotrebnih operacija. Teicherov zbir može pomoći u prepoznavanju bolesnica s akutnom upalom crvuljka. Niti jedan zbir se ne može koristiti kao jedino sredstvo za indiciranje ili nepoduzimanje operacije akutne upale crvuljka u svim slučajevima. Bodovni sustav može biti koristan u isticanju važnih kliničkih znakova i simptoma u pojedinim skupinama bolesnika.

Ključne riječi: Apendicitis - dijagnostika; Žene; Osjetjivost; Specifičnost; Krivulja ROC; Prediktivna vrijednost 